\title{
Model calculations of nitrate leaching during the growth period of potatoes
}

\author{
J. J. NEETESON ${ }^{1}$, D. J. GREENWOOD ${ }^{2} \&$ A. DRAYCOTT ${ }^{2}$ \\ ${ }^{1}$ Institute for Soil Fertility, P.O. Box 30003, NL 9750 RA Haren, Netherlands \\ ${ }^{2}$ Institute of Horticultural Research, Wellesbourne, Warwick CV35 9EF, UK
}

Received 7 April 1989; accepted 21 April 1989

\begin{abstract}
To estimate the amount of nitrate lost due to leaching during the growth period of potatoes and the amount of mineral nitrogen present in the soil at harvest time, i.e. residual mineral nitrogen, calculations were performed with a previously derived simulation model for the response of potatoes to nitrogen. In the calculations those factors were varied that were considered to affect the amount of nitrate lost due to leaching: precipitation in spring and summer, soil type, mineralization rate of soil organic matter, and amount of fertilizer nitrogen applied. It was calculated that the total loss of nitrogen, i.e. the amounts leached in spring plus the amounts accumulated as residual soil mineral nitrogen, were similar in a loamy sand and a clay loam. The greater loss by leaching from the sand was offset by the greater accumulation of mineral nitrogen in the loam. Under normal conditions of precipitation and mineralization the total loss increased from about $20 \mathrm{~kg} \mathrm{~N}$ per ha at a fertilizer nitrogen application rate of $200 \mathrm{~kg} \mathrm{~N}$ per ha to about $190 \mathrm{~kg} \mathrm{~N}$ per ha at a rate of $400 \mathrm{~kg} \mathrm{~N}$ per ha. At a high rate of mineralization, an application as low as $100 \mathrm{~kg}$ fertilizer $\mathrm{N}$ per ha resulted in a total loss of about $60 \mathrm{~kg} \mathrm{~N}$ per ha. It was concluded that little nitrate leaching occurs when the current nitrogen fertilizer recommendations are followed, provided that mineralization in the soil proceeds at an average rate. When high mineralization rates are likely to occur, however, the recommendations should be lowered.
\end{abstract}

Keywords: fertilizer nitrogen, nitrate leaching, nitrogen mineralization, potatoes, residual soil mineral nitrogen, simulation model

\section{Introduction}

As there is generally a large interval between the time of application (usually in March) and the period of major uptake of nitrogen by the potatoes (June-July; Dyson \& Watson, 1971), fertilizer nitrogen applied to this crop can be subject to leaching in spring. Since potatoes are rather inefficient users of nitrogen (Prins et al., 1988), nitrogen not taken up by the crop could also be leached in summer, or it could accumulate in the soil, and then be leached out of it in autumn and winter, when the soil is fallow and there is no crop to absorb nitrate. 


\section{J. J. NEETESON, D. J. GREENWOOD AND A. DRAYCOTT}

However, reports of direct measurements of nitrate leaching during the growth of potatoes in field experiments could not be found, and data on accumulation of soil mineral nitrogen after potato cropping proved to be scarce (Prins et al., 1988). Since it is expensive to perform such field experiments, we attempted in this paper to predict nitrate leaching and accumulation of soil mineral nitrogen in a cheaper and less time-consuming way by means of dynamic simulation. For this purpose a slightly modified version of a previously derived model was used. It has predicted responses to nitrogen satisfactorily, not only for potatoes (Greenwood et al., 1985b; Neeteson et al., 1987), but also for various vegetable crops (Greenwood \& Draycott, 1989).

In the calculations those factors were varied that were considered to have most effect on nitrate leaching, i.e. precipitation in spring and summer, soil type, mineralization rate of soil organic matter, and amount of fertilizer nitrogen applied.

\section{Materials and methods}

\section{Model}

The calculations were performed with the simulation model for the response of potatoes to nitrogen (Greenwood et al., 1985b; Neeteson et al., 1987), modified as described by Greenwood \& Draycott (1989) to take account of the decline in apparent recovery of soil mineral nitrogen by the crop with increase in nitrogen status of the crop; apparent recovery varied by about $15 \%$. The model calculates on a daily basis potential and actual increase in total dry weight of the potato crop, potential and actual uptake of nitrogen by the crop, mineralization of soil organic matter, soil moisture content, redistribution of nitrate through the soil profile, and depth of rooting. The field-dependent inputs required by the model are amount of soil mineral nitrogen in early spring, time and rate of fertilizer nitrogen application, mineralization rate, time of planting of the potato tubers, maximum dry weight of tuber plus foliage, maximum depth of rooting, field capacity of the soil, daily values of soil temperature at $10 \mathrm{~cm}$ depth, daily values of precipitation surplus, and evaporation from an open water surface.

The potato crop is visualized as growing on soil that is divided into 5-cm-thick layers. From the expected maximum dry weight and the time between emergence and termination of crop growth, the model first calculates a growth rate coefficient for plants that are not subjected to any nitrogen stress. As the crop grows, the roots penetrate more and more of the $5-\mathrm{cm}$ layers and are able to extract mineral nitrogen from them. The minimum concentration below which the roots are unable to absorb mineral nitrogen from a soil layer was considered to be $0.46 \mathrm{~kg} \mathrm{~N}$ per $\mathrm{cm}$ of soil, but all mineral nitrogen above that concentration was deemed available for uptake by the crop. The nitrogen demand of the crop depends on its dry weight. Actual uptake is less than demand when there is insufficient available mineral nitrogen in the soil. In that case the growth rate of the crop is restricted. It is assumed that all soil mineral nitrogen is in the form of nitrate, because in Dutch soils the rate of nitri- 
fication is generally much higher than the rate of mineralization. Moreover, fertilizer ammonium is usually nitrified within a few weeks after application. Mineralization of soil organic matter is assumed to proceed at a fixed rate which is only dependent on soil temperature. Mineralization is considered to take place almost entirely in the upper $30 \mathrm{~cm}$ of soil. Leaching of nitrate is described according to Burns (1974).

\section{Model calculations}

Model calculations were made for five application rates of fertilizer nitrogen, and combinations of amounts of precipitation in spring (March-May) and summer (June-August), two field capacities of the soil, and two rates of nitrogen mineralization (Table 1).

The various amounts of precipitation in spring and summer were chosen on the basis of the frequency distributions of the total amounts of precipitation in spring and summer as measured at the central meteorological station in the Netherlands during the period 1906-1988 (Fig. 1). For each period a normal and a wet year were chosen (Table 1). Precipitation in 1965, the year in which total precipitation in March-August was the largest for the period 1906-1988, was also included in the calculations. The daily rainfall in the three springs and three summers is shown in Figs. 2 and 3 , respectively. The spring and summer precipitation inputs in the model are given in Table 2 .

Table 1. Variable inputs in the model.

\begin{tabular}{|c|c|}
\hline Parameter & Values \\
\hline $\begin{array}{l}\text { Precipitation March-May } \\
\text { (mm) }\end{array}$ & $\begin{array}{l}188(1939) \\
241(1987) \\
272(1965)\end{array}$ \\
\hline $\begin{array}{l}\text { Precipitation June-August } \\
\quad(\mathrm{mm})\end{array}$ & $\begin{array}{l}227(1972) \\
308(1968) \\
353(1965)\end{array}$ \\
\hline $\begin{array}{l}\text { Field capacity of the soil } \\
\qquad\left(\mathrm{cm} \mathrm{cm} \mathrm{cm}^{-3}\right)\end{array}$ & $\begin{array}{l}0.27(0-30 \mathrm{~cm}), 0.20(30-90 \mathrm{~cm}) \\
0.33(0-30 \mathrm{~cm}), 0.32(30-90 \mathrm{~cm})\end{array}$ \\
\hline $\begin{array}{l}\text { Mineralization rate at } 12^{\circ} \mathrm{C} \\
(\mathrm{kg} \mathrm{N} \text { per ha per day) }\end{array}$ & $\begin{array}{l}1 \\
2\end{array}$ \\
\hline $\begin{array}{l}\text { Fertilizer nitrogen application rate } \\
\quad(\mathrm{kg} \mathrm{N} \text { per ha) }\end{array}$ & $\begin{array}{r}0 \\
100 \\
200 \\
300 \\
400\end{array}$ \\
\hline
\end{tabular}




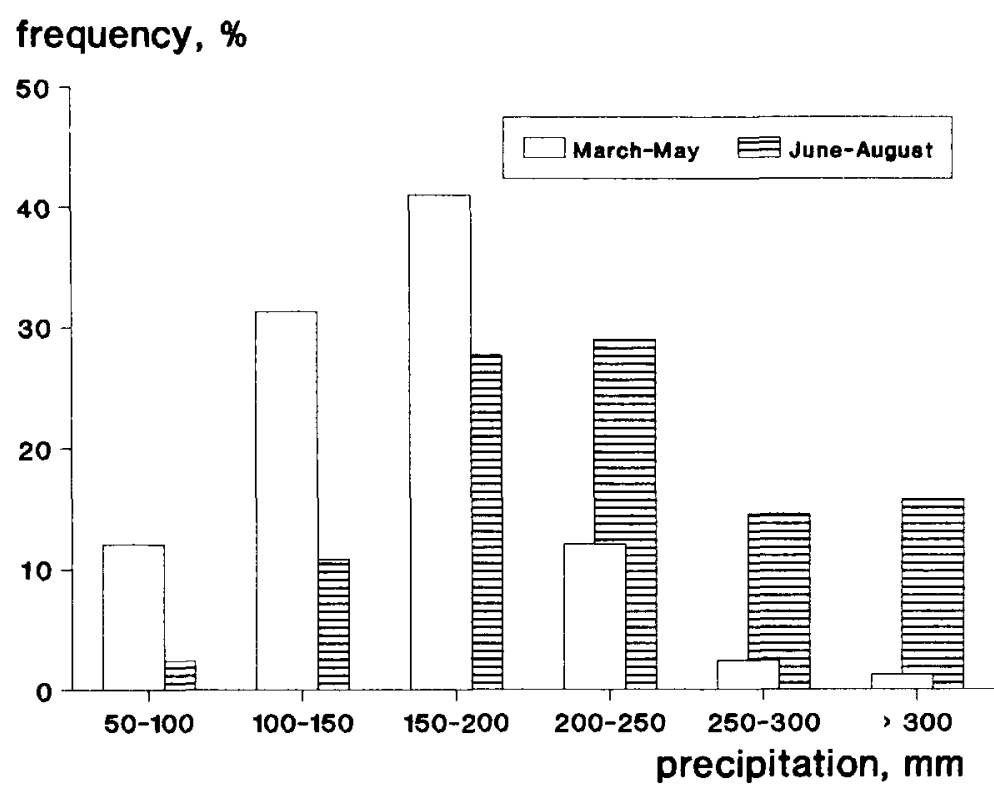

Fig. 1. Frequency distribution of cumulative precipitation in spring (March-May) and summer (JuneAugust) at the central meteorological station in the period 1906-1988. Data derived from Anon. (19061988).

The field capacities of the soil were chosen as being representative of a loamy sand and a clay loam (Wösten et al., 1987).

The mineralization rates of 1.0 and $2.0 \mathrm{~kg} \mathrm{~N}$ per ha per day were chosen, because in field experiments with potatoes it was found earlier that these values corresponded to the average and maximum value of nitrogen mineralization (Neeteson et al., 1987).

The inputs of the model, having values that were identical for each calculation, are given in Table 3.

The data listed in Table 3 were chosen as being typical for potato culture in the Netherlands, as are those on amount of soil mineral nitrogen in early spring and the distribution over the soil layers, and dry weight of tubers planted $(2 t$ fresh tubers per ha with a dry-matter content of $25 \%$ ).

The recovery of nitrogen by the tops plus the tubers at low nitrogen nutrition was set at $80 \%$, as was done in some previous studies (Greenwood et al., 1985b).

The maximum rooting depth of $60 \mathrm{~cm}$ and the maximum total dry weight of $17.5 \mathrm{t}$ $\mathrm{ha}^{-1}$ were assumed to be representative of a high-yielding potato crop.

Long-term averages of the daily evaporation and soil temperature measurements at the central meteorological station (Anon., 1989) were used. Evaporation varied between 1.4 and $4.0 \mathrm{~mm}$ per day; soil temperature at $10 \mathrm{~cm}$ depth varied between 3.0 and $17.1{ }^{\circ} \mathrm{C}$. 
NITRATE LEACHING DURING THE GROWTH PERIOD OF POTATOES

a

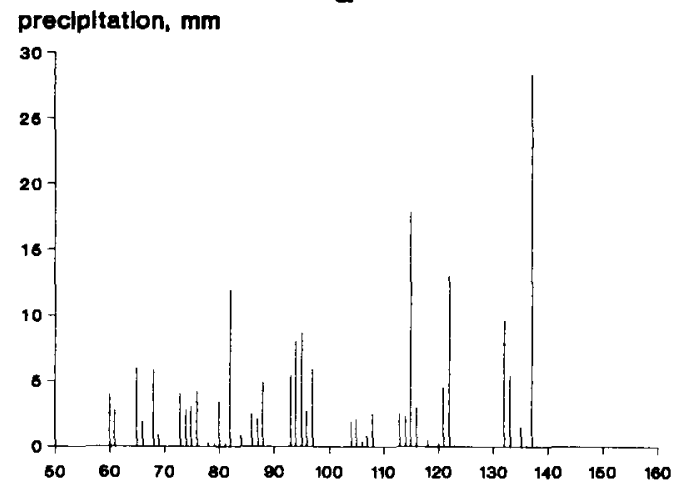

b

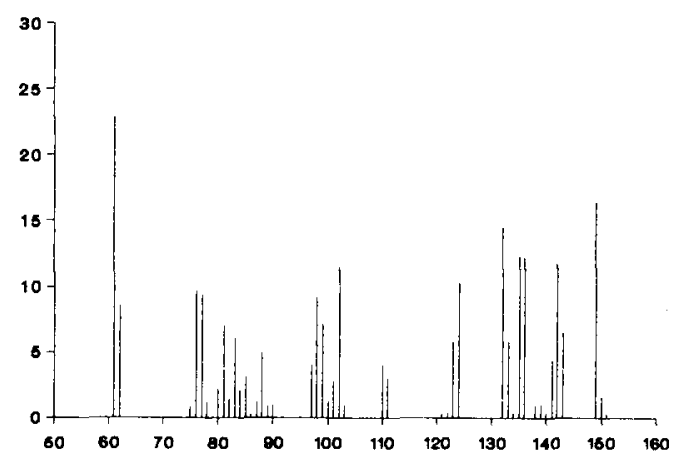

C

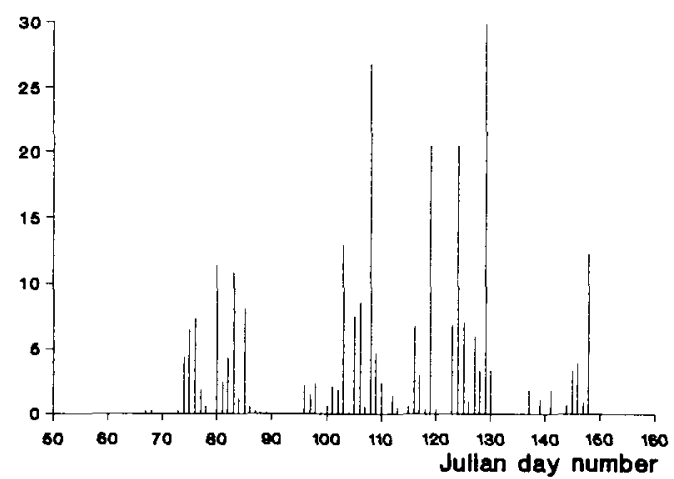

Fig. 2. Daily values of precipitation in spring (March-May $=$ Julian day 60-Julian day 151) at the central meteorological station in 1939 (normal, a), 1987 (wet, b), and 1965 (extremely wet, c). Data derived from Anon. (1906-1988). 


\section{J. J. NEETESON, D. J. GREENWOOD AND A. DRAYCOTT}

a

precipltation, $\mathrm{mm}$

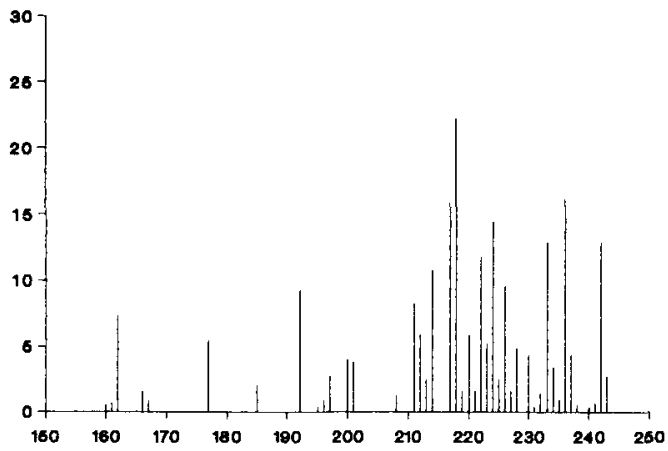

b
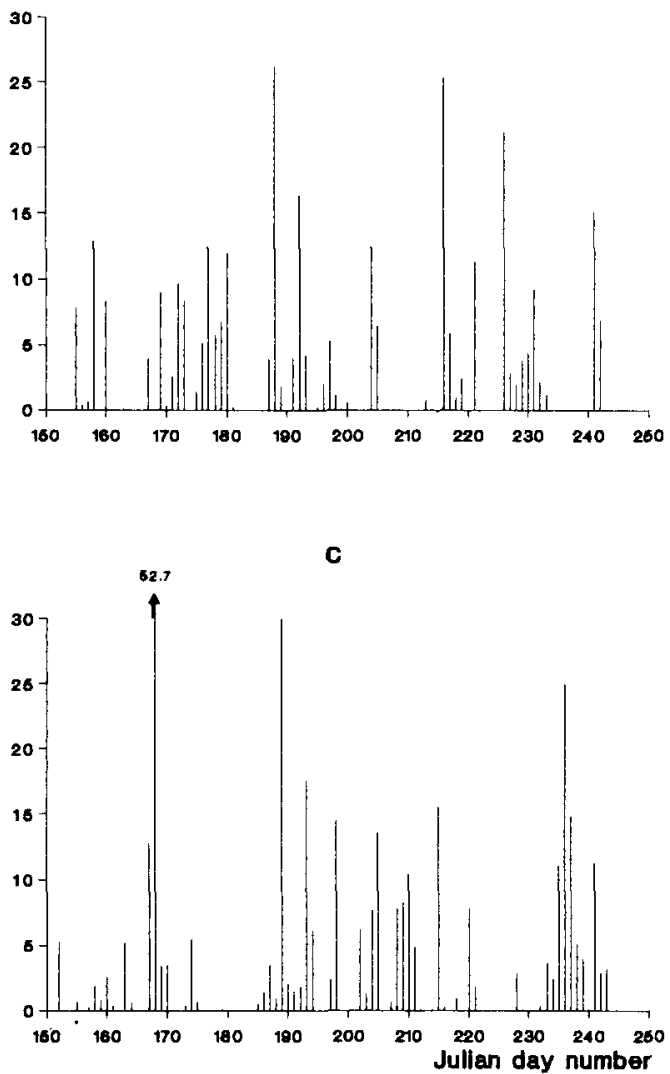

Fig. 3. Daily values of precipitation in summer (June-August = Julian day 152-Julian Day 243) at the central meteorological station in 1972 (normal, a), 1968 (wet, b), and 1965 (extremely wet, c). Data derived from Anon. (1906-1988). 
Table 2. Precipitation treatments. $\mathrm{N}=$ normal, $\mathrm{W}=$ wet.

\begin{tabular}{lll}
\hline Symbol & \multicolumn{2}{l}{ Precipitation $(\mathrm{mm})$} \\
\cline { 2 - 3 } & March-May & June-August \\
NN & 188 & 227 \\
NW & 188 & 308 \\
WN & 241 & 227 \\
WW & 241 & 308 \\
1965 & 272 & 353 \\
\hline
\end{tabular}

Table 3. Standard inputs in the model.

\begin{tabular}{lc}
\hline Parameter & Date or value \\
& \\
Measurement of soil mineral nitrogen in early spring & $1 \mathrm{March}$ \\
Fertilizer nitrogen application & $15 \mathrm{March}$ \\
Planting of tubers & $1 \mathrm{April}$ \\
End of crop growth & 1 September \\
Soil mineral nitrogen in the $0-30 \mathrm{~cm}$ layer on $1 \mathrm{March}$ & $25 \mathrm{~kg} \mathrm{~N}$ per ha \\
Soil mineral nitrogen in the $30-60 \mathrm{~cm}$ layer on $1 \mathrm{March}$ & $25 \mathrm{~kg} \mathrm{~N}_{\text {per ha }}$ \\
Dry weight of tubers planted & $0.5 \mathrm{t} \mathrm{ha}^{-1}$ \\
Recovery of soil mineral N at low N nutrition & $80 \%$ \\
Maximum rooting depth & $60 \mathrm{~cm}^{-1}$ \\
Maximum total dry weight of the crop & $17.5 \mathrm{t} \mathrm{ha}^{-1}$ \\
\end{tabular}

\section{Results}

\section{Yield and nitrogen uptake}

With the exception of the treatment involving the average rate of mineralization in 1965 on the loamy sand, the model calculations which included the various amounts of precipitation in spring showed that the maximum yield of foliage plus tubers was always obtained with the highest fertilizer nitrogen level (Fig. 4). Fig. 4 also shows that the mineralization rate had a considerable effect on the response to fertilizer nitrogen. The treatments with various amounts of precipitation in summer are not shown in Fig. 4, because precipitation in summer did not affect yield.

Like yield, maximum uptake of nitrogen by the foliage plus tubers, i.e. $300 \mathrm{~kg} \mathrm{~N}$ per ha, was also nearly always obtained with the highest level of fertilizer nitrogen (Fig. 5). On the sandy loam in 1965 nitrogen uptake did not exceed $200 \mathrm{~kg} \mathrm{~N}$ per ha at the average mineralization rate, even when $400 \mathrm{~kg}$ fertilizer nitrogen was applied. In this situation a serious shortage of available soil mineral nitrogen occurred. Results with various amounts of precipitation in summer are not shown here, because precipitation in summer did not affect uptake of nitrogen. 
dry weight, $\mathrm{t} \mathrm{ha}^{-1}$

a

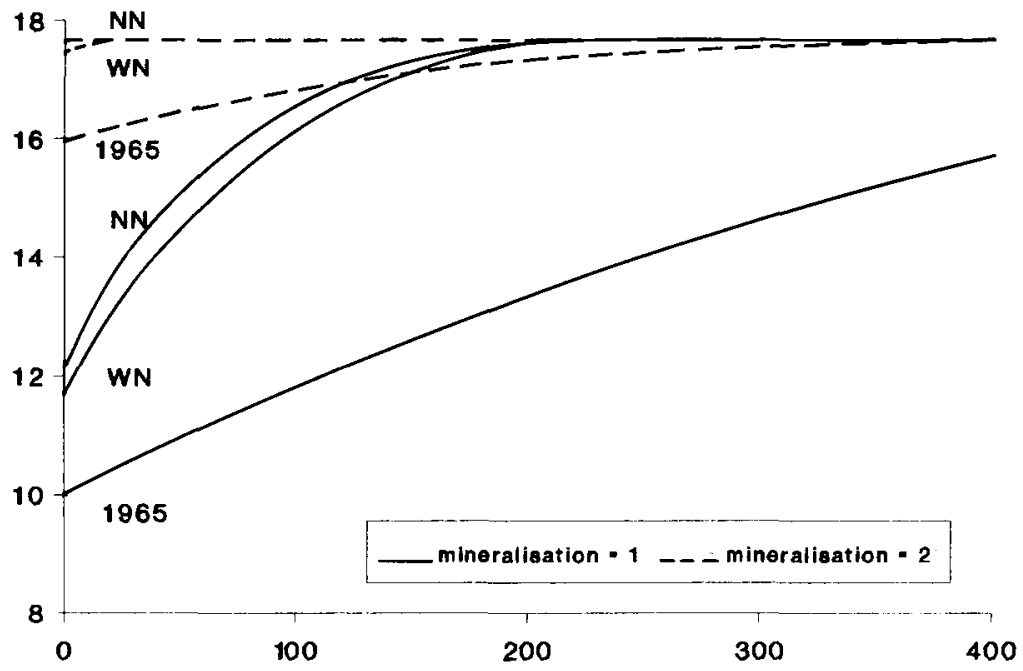

b

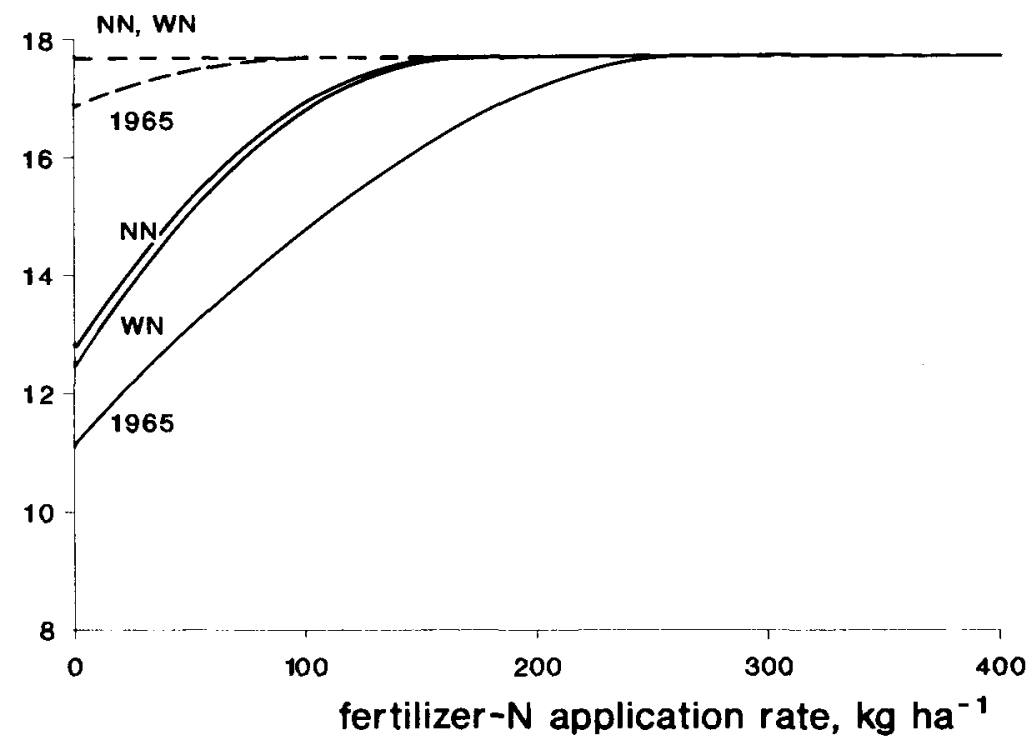

Fig. 4. Effect of fertilizer nitrogen application rate on dry weight of foliage plus tubers on the loamy sand (a) and the clay loam (b). The values 1 and 2 are the mineralization rates in $\mathrm{kg} \mathrm{N}$ per ha per day. See Table 2 for meaning of symbols. 
$\mathrm{N}$ uptake, $\mathrm{kg} \mathrm{ha}^{-1}$

a

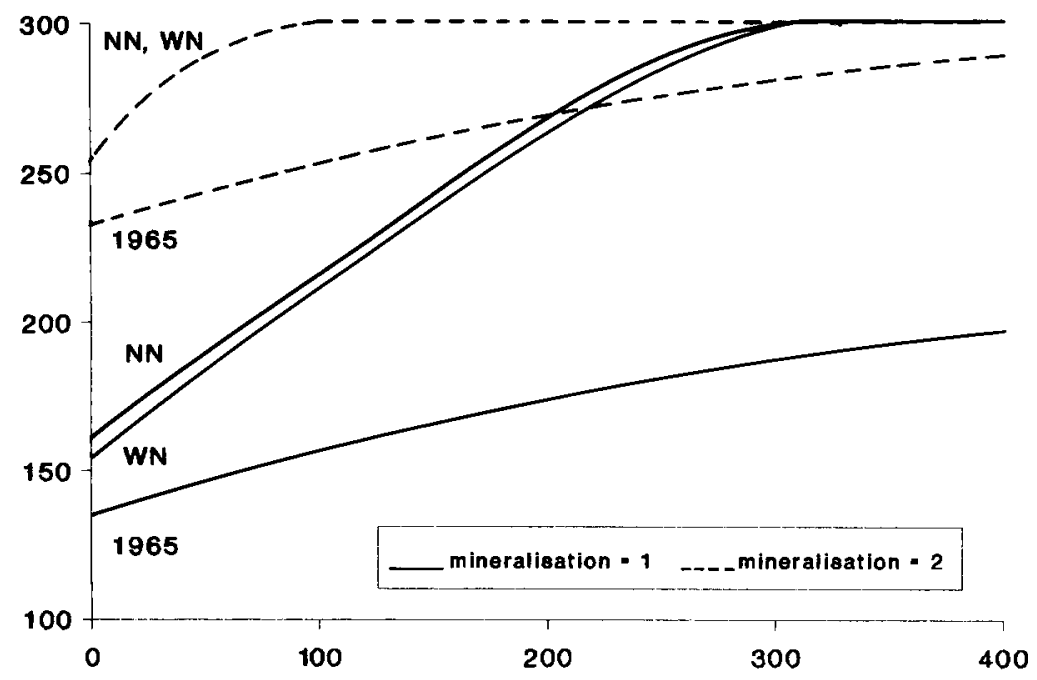

b

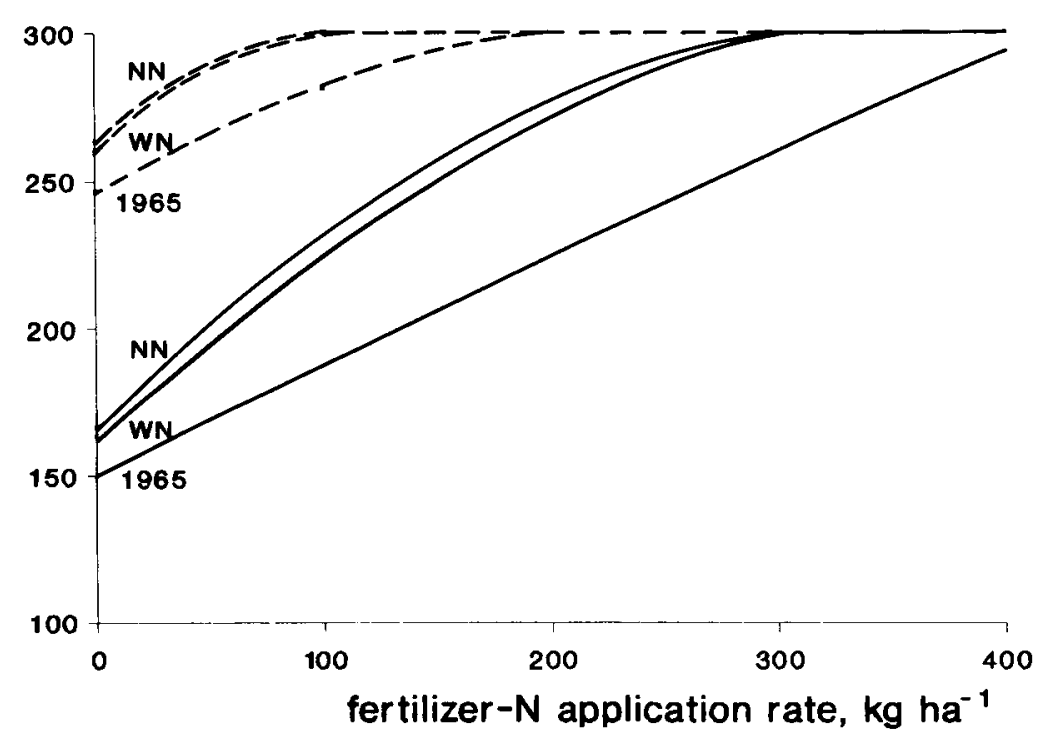

Fig. 5. Effect of fertilizer nitrogen application rate on nitrogen uptake by the foliage plus the tubers on the loamy sand (a) and the clay loam (b). The values 1 and 2 are the mineralization rates in $\mathrm{kg} \mathrm{N}$ per ha per day. See Table 2 for meaning of symbols. 


\section{Nitrate leached during the growth period}

Nitrate is assumed to be lost due to leaching when it moves below the root zone, i.e. the $0-60 \mathrm{~cm}$ layer of the soil.

Calculations with the model showed that during a spring with normal precipitation $27 \mathrm{~kg} \mathrm{~N}$ per ha was lost from the loamy sand and $16 \mathrm{~kg} \mathrm{~N}$ per ha from the clay loam when no fertilizer nitrogen was applied (Table 4). This was the result of a combination of factors: the soil was at field capacity on 1 March, rain fell in early March (day 60-69: Fig. 2a), and evaporation was low in this period. In normal and wet springs only a small percentage of fertilizer nitrogen $(2-6 \%)$ was lost from the loamy sand, whereas loss of fertilizer nitrogen from the clay loam was negligible. However, in the extremely wet spring of 1965 about $75 \%$ of the $400 \mathrm{~kg}$ fertilizer nitrogen applied was lost from the loamy sand and about $35 \%$ from the clay loam (Table 4). The same percentages were lost in 1965 at the other fertilizer levels (Fig. 6). With the exception of the very wet summer of 1965, when less than $10 \mathrm{~kg} \mathrm{~N}$ per ha was lost, no leaching occurred in summer (Table 4).

During normal and wet springs the rate of nitrogen mineralization hardly affected the amounts of nitrate lost from the two soils (Fig. 7). An exception was the extremely wet spring of 1965 , when more nitrate was lost at the high rate than at the average rate of mineralization; the difference amounted to about $25 \mathrm{~kg} \mathrm{~N}$ per ha for the loamy sand and about $10 \mathrm{~kg}$ per ha for the clay loam.

Since fertilizer nitrogen application and rate of nitrogen mineralization appeared to have little effect on the magnitude of the losses of nitrate in normal and wet springs, the nitrate lost thus originated from nitrate already present in the deeper soil layers in early spring. Additional calculations with various amounts of soil mineral nitrogen in the $30-60 \mathrm{~cm}$ layer in early spring showed that the amount of nitrate

Table 4. Nitrate lost due to leaching in spring (March-May) and summer (June-August). Mineralization rate is $1 \mathrm{~kg} \mathrm{~N}$ per ha per day at $12^{\circ} \mathrm{C}$. $0 \mathrm{~N}=$ no fertilizer nitrogen application; $400 \mathrm{~N}=$ a fertilizer nitrogen application rate of $400 \mathrm{~kg} \mathrm{ha}^{-1}$. See Table 2 for meaning of symbols.

\begin{tabular}{|c|c|c|c|c|c|}
\hline \multirow[t]{3}{*}{ Soil type } & \multirow[t]{3}{*}{ Treatment } & \multicolumn{4}{|c|}{ Nitrate leached (kg N per ha) } \\
\hline & & \multicolumn{2}{|c|}{ spring } & \multicolumn{2}{|c|}{ summer } \\
\hline & & $0 \mathrm{~N}$ & $400 \mathrm{~N}$ & $0 N$ & $400 \mathrm{~N}$ \\
\hline \multirow[t]{5}{*}{ Loamy sand } & NN & 27 & 36 & 0 & 0 \\
\hline & NW & 27 & 36 & 0 & 0 \\
\hline & WN & 35 & 60 & 0 & 0 \\
\hline & WW & 35 & 60 & 0 & 0 \\
\hline & 1965 & 58 & 355 & 5 & 1 \\
\hline \multirow[t]{5}{*}{ Clay loam } & NN & 16 & 17 & 0 & 0 \\
\hline & NW & 16 & 17 & 0 & 0 \\
\hline & WN & 23 & 25 & 0 & 0 \\
\hline & WW & 23 & 25 & 0 & 0 \\
\hline & 1965 & 44 & 180 & 3 & 9 \\
\hline
\end{tabular}




\section{nitrate leached, $\mathrm{kg} \mathrm{N}$ per ha}

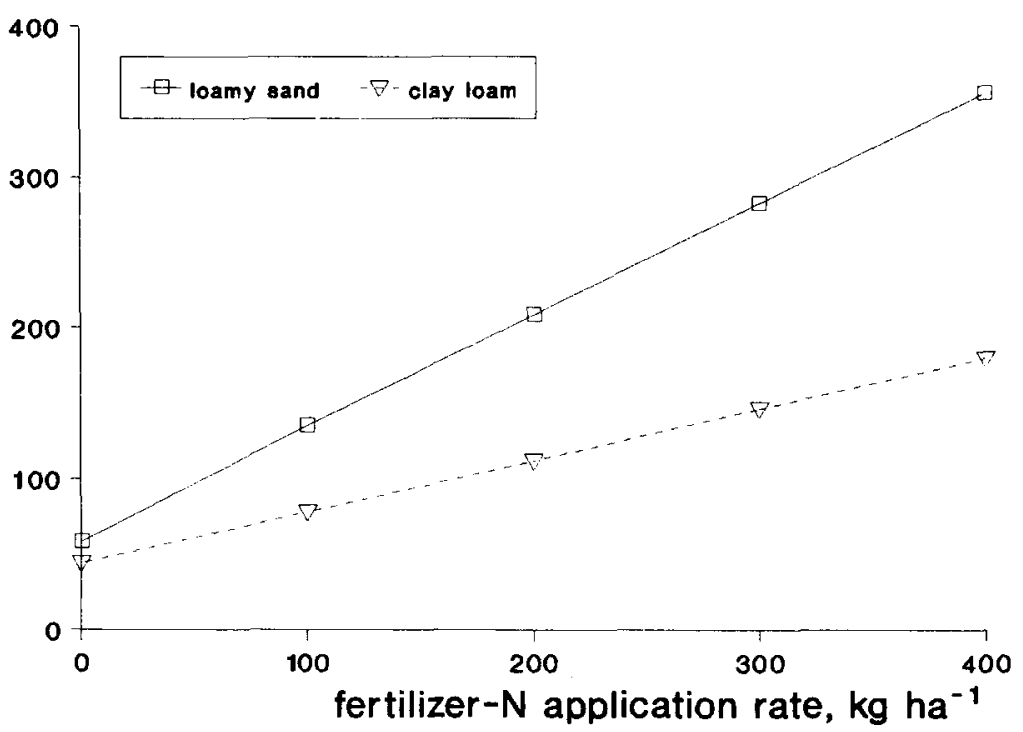

Fig. 6. Effect of fertilizer nitrogen application rate on amount of nitrate lost due to leaching from the loamy sand and the clay loam in the extremely wet spring of 1965 . Mineralization rate is $1 \mathrm{~kg} \mathrm{~N}$ per ha per day.

lost in a normal spring heavily depended on the amount of mineral nitrogen present in this soil layer (Fig. 8). About $75 \%$ of the mineral nitrogen present in this layer was lost from the loamy sand, and about $60 \%$ from the clay loam.

\section{Residual soil mineral nitrogen}

The amounts of soil mineral nitrogen in the $0-60 \mathrm{~cm}$ layer when potato growth had ceased (1 September), i.e. residual soil mineral nitrogen, without fertilizer nitrogen and with the highest fertilizer nitrogen application rate are shown in Table 5. Without application of fertilizer, the amount of residual soil mineral nitrogen was always the smallest possible: $28 \mathrm{~kg} \mathrm{~N}$ per ha, i.e. $0.46 \mathrm{~kg} \mathrm{~N}$ per ha per $\mathrm{cm}$ of soil (see Section 'Materials and methods'). When $400 \mathrm{~kg}$ fertilizer nitrogen was applied per ha, substantially larger amounts of residual soil mineral nitrogen were found than without fertilizer nitrogen application, especially at the higher mineralization rate (Table 5 ). The difference tended to decrease with increasing wetness of the spring. Precipitation in summer did not affect residual soil mineral nitrogen. With the exception of 1965 , the amount of residual soil mineral nitrogen was always larger in the clay loam than in the loamy sand (Table 5). With the exception of the clay loam at the higher mineralization rate, in 1965 residual soil mineral nitrogen was at the minimum level, irrespective of the rate of fertilizer nitrogen applied.

The effect of fertilizer nitrogen level on the amount of residual soil mineral nitro- 


\section{J. J. NEETESON, D. J. GREENWOOD AND A. DRAYCOTT}

\section{nitrate leached,}

a

\section{$\mathrm{kg} \mathrm{N}$ per ha}
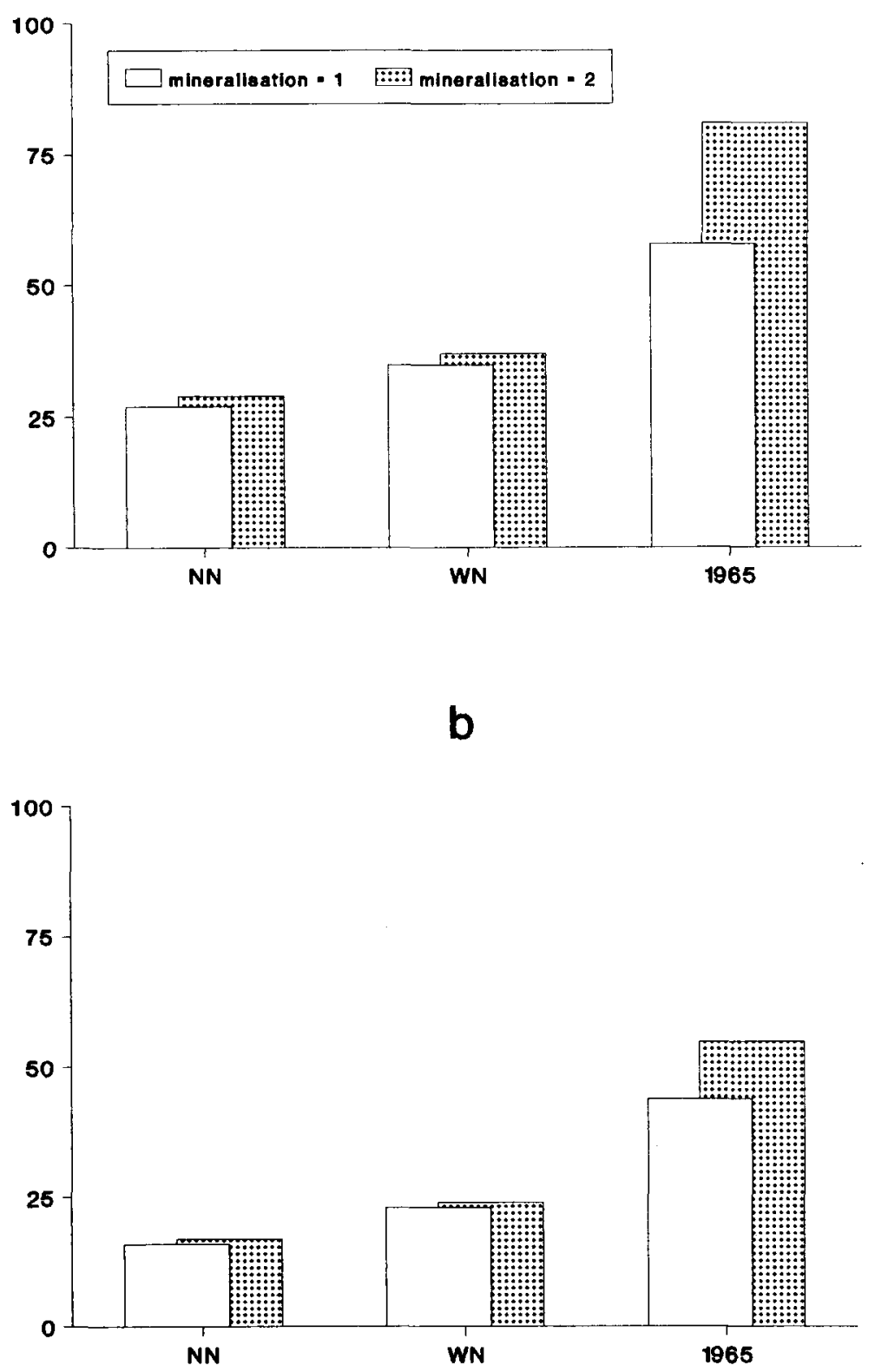

Fig. 7. Nitrate lost due to leaching from the loamy sand (a) and the clay loam (b) in a normal, a wet, and an extremely wet spring with various nitrogen mineralization rates when no fertilizer nitrogen is applied. The values 1 and 2 are the mineralization rates in $\mathrm{kg} \mathrm{N}$ per ha per day. See Table 2 for meaning of symbols. 


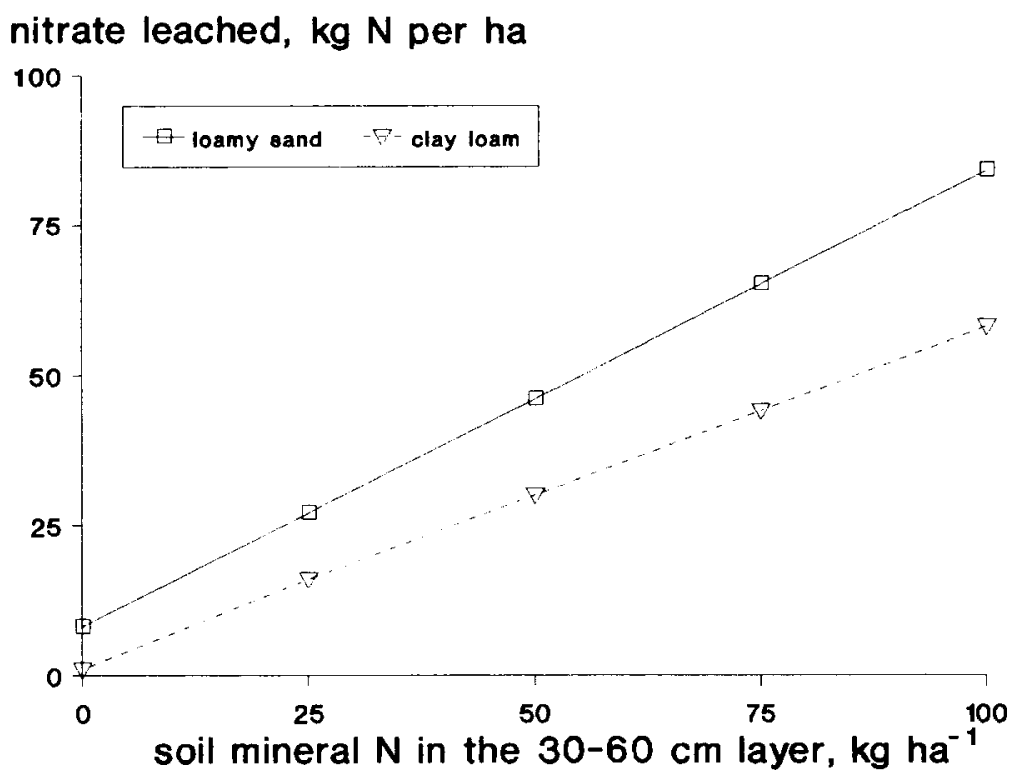

Fig. 8. Effect of soil mineral nitrogen in the $30-60 \mathrm{~cm}$ layer in early spring on the amount of nitrate lost due to leaching from the loamy sand and the clay loam in a spring with normal precipitation. Mineralizaion rate is $1 \mathrm{~kg} \mathrm{~N}$ per ha per day.

gen in the two soil types is shown in Fig. 9. The results presented in this figure refer to a spring and a summer with normal precipitation. At the average rate of mineralization, soil mineral nitrogen accumulated when fertilizer nitrogen levels exceeded $200 \mathrm{~kg} \mathrm{~N}$ per ha (Fig. 9a), but at the high mineralization rate accumulation occurred when only $100 \mathrm{~kg} \mathrm{~N}$ per ha was applied (Fig. 9b).

Table 5. Residual soil mineral nitrogen in the $0-60 \mathrm{~cm}$ layer. $0 \mathrm{~N}=$ no fertilizer nitrogen application; $400 \mathrm{~N}=$ a fertilizer nitrogen application rate of $400 \mathrm{~kg} \mathrm{ha}^{-1}$. See Table 2 for meaning of symbols.

\begin{tabular}{|c|c|c|c|c|c|}
\hline \multirow{3}{*}{$\begin{array}{l}\text { Minerali- } \\
\text { zation rate } \\
\text { (kg N per } \\
\text { ha per day) }\end{array}$} & \multirow[t]{3}{*}{ Treatment } & \multicolumn{4}{|c|}{ Residual soil mineral nitrogen (kg N per ha) } \\
\hline & & \multicolumn{2}{|c|}{ loamy sand } & \multicolumn{2}{|c|}{ clay loam } \\
\hline & & $0 \mathrm{~N}$ & $400 \mathrm{~N}$ & $0 \mathrm{~N}$ & $400 \mathrm{~N}$ \\
\hline \multirow[t]{5}{*}{1} & NN & 28 & 181 & 28 & 201 \\
\hline & NW & 28 & 181 & 28 & 201 \\
\hline & WN & 28 & 155 & 28 & 194 \\
\hline & WW & 28 & 155 & 28 & 194 \\
\hline & 1965 & 28 & 28 & 28 & 28 \\
\hline \multirow[t]{5}{*}{2} & NN & 28 & 376 & 28 & 397 \\
\hline & NW & 28 & 376 & 28 & 397 \\
\hline & WN & 28 & 349 & 28 & 389 \\
\hline & WW & 28 & 349 & 28 & 389 \\
\hline & 1965 & 28 & 28 & 28 & 138 \\
\hline
\end{tabular}


residual soil

\section{mineral $\mathrm{N}, \mathrm{kg} \mathrm{ha}^{-1}$}

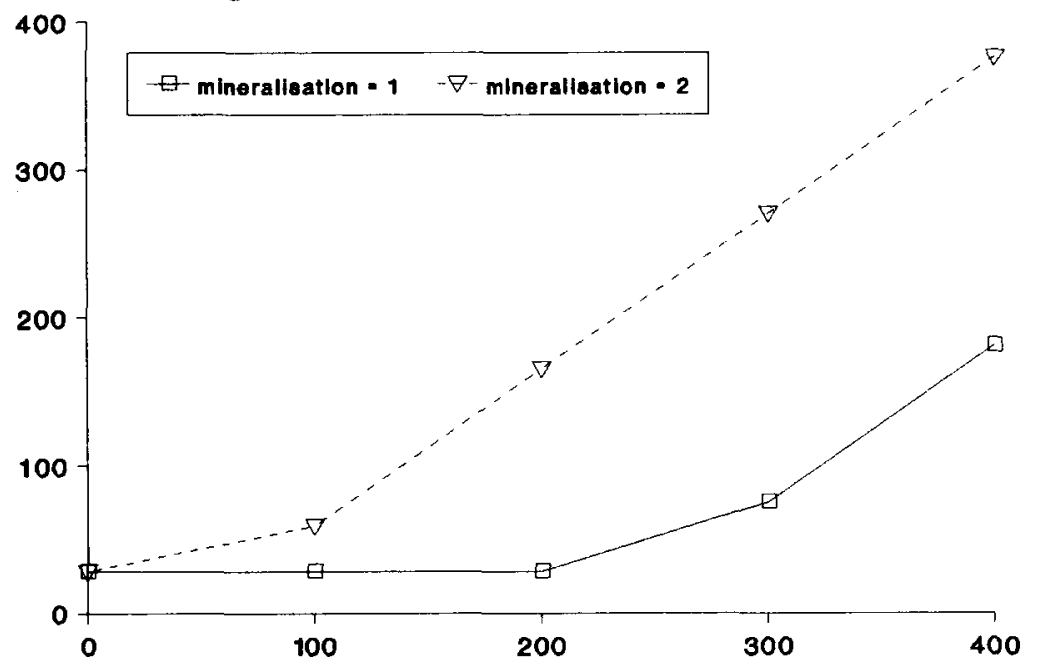

b

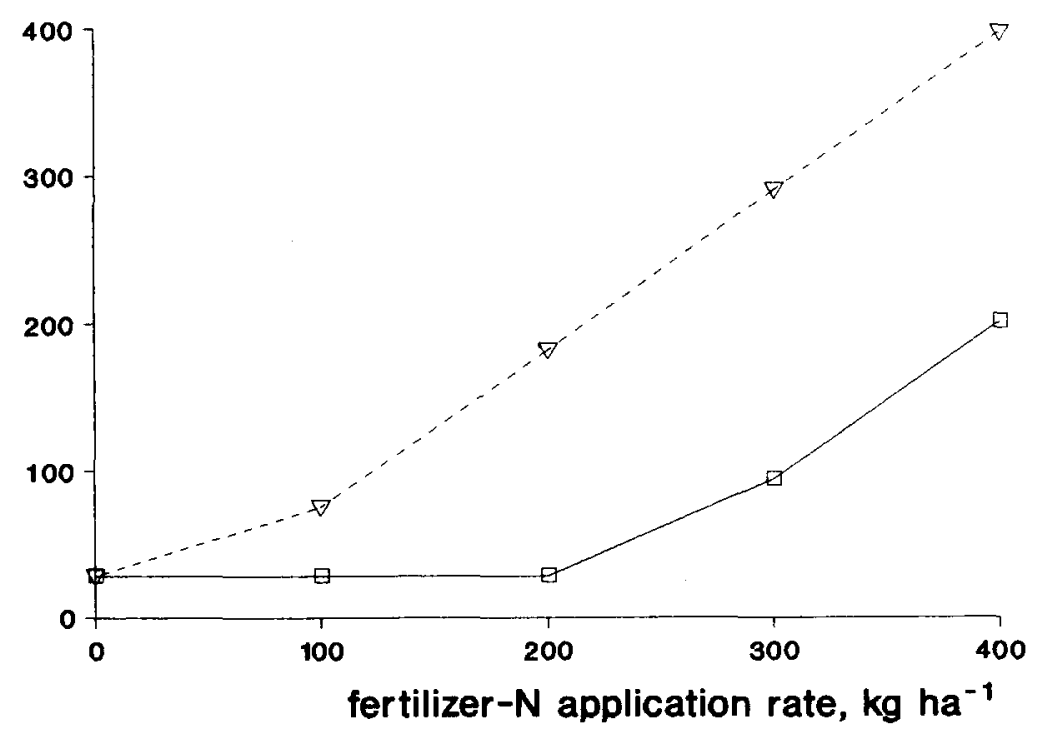

Fig. 9. Effect of fertilizer nitrogen application rate on amount of residual soil mineral nitrogen in the 0 $60 \mathrm{~cm}$ layers of the loamy sand (a) and the clay loam (b) after a spring and summer with normal precipitation. The values 1 and 2 are the mineralization rates in $\mathrm{kg} \mathrm{N}$ per ha per day. 


\section{Nitrate leaching plus accumulation of residual soil mineral nitrogen}

The total loss of nitrogen due to leaching is considered to be the sum of the calculated loss during spring and summer plus the amount of soil mineral nitrogen accumulated at harvest because this nitrate will generally be leached in the following autumn and winter. In normal and wet springs the total losses of $\mathrm{N}$ from the loamy sand and the clay loam were similar (Figs 10 and 11). The greater loss by leaching in spring from the loamy sand was offset by the greater accumulation of residual soil mineral nitrogen in the clay loam. At the average rate of mineralization the total loss of nitrogen after normal and wet springs increased from about $20 \mathrm{~kg} \mathrm{~N}$ per ha at a fertilizer nitrogen application rate of $200 \mathrm{~kg} \mathrm{~N}$ per ha to about $190 \mathrm{~kg} \mathrm{~N}$ per ha at a rate of $400 \mathrm{~kg} \mathrm{~N}$ per ha (Fig. 10). After normal and wet springs, an application as low as $100 \mathrm{~kg}$ fertilizer $\mathrm{N}$ per ha resulted in a total loss of about $60 \mathrm{~kg} \mathrm{~N}$ per ha at the high rate of mineralization. At an application rate of $400 \mathrm{~kg} \mathrm{~N}$ per ha the total loss amounted to almost $400 \mathrm{~kg} \mathrm{~N}$ per ha (Fig. 11). This loss was mainly due to accumulation of residual soil mineral nitrogen.

\section{Discussion}

\section{Nitrate leaching}

The calculations showed that in normal and wet springs, nitrate present in the upper layers of soil in early spring, viz. fertilizer nitrogen, or nitrate produced in the upper layers of soil during spring, viz. mineralized soil nitrogen which is nitrified, does not move below the root zone. Duynisveld et al. (1988) also showed that there is little danger that nitrate present close to the soil surface in early March leaves the root zone of the crop. The nitrate lost during normal and wet springs thus originates from nitrate already present in the deeper soil layers. The calculations showed that a large part of the mineral nitrogen present in the $30-60 \mathrm{~cm}$ layer at the end of the winter was lost due to leaching in spring. This implies that the presence during winter of a cover crop that absorbs nitrogen from the $30-60 \mathrm{~cm}$ layer will help to minimize leaching not only during the winter period, but also during spring.

The calculations also showed that substantial leaching of fertilizer nitrogen (up to $75 \%$ of the amount applied) or of nitrogen mineralized in spring occurred during the extremely wet spring of 1965 . Under such conditions, nitrate originally present in the upper layers of soil then moves below the root zone. The chance of such wet springs occurring is, however, small: only about $5 \%$ (Fig. 1).

It was shown that leaching of nitrate did not occur at all during dry to wet summers, and was negligible during extremely wet summers. Leaching did not occur because the soils hardly reached field capacity in summer due to high evapotranspiration (de Willigen, 1986).

\section{Residual soil mineral nitrogen}

The amount of residual soil mineral nitrogen as calculated by the model is the dif- 

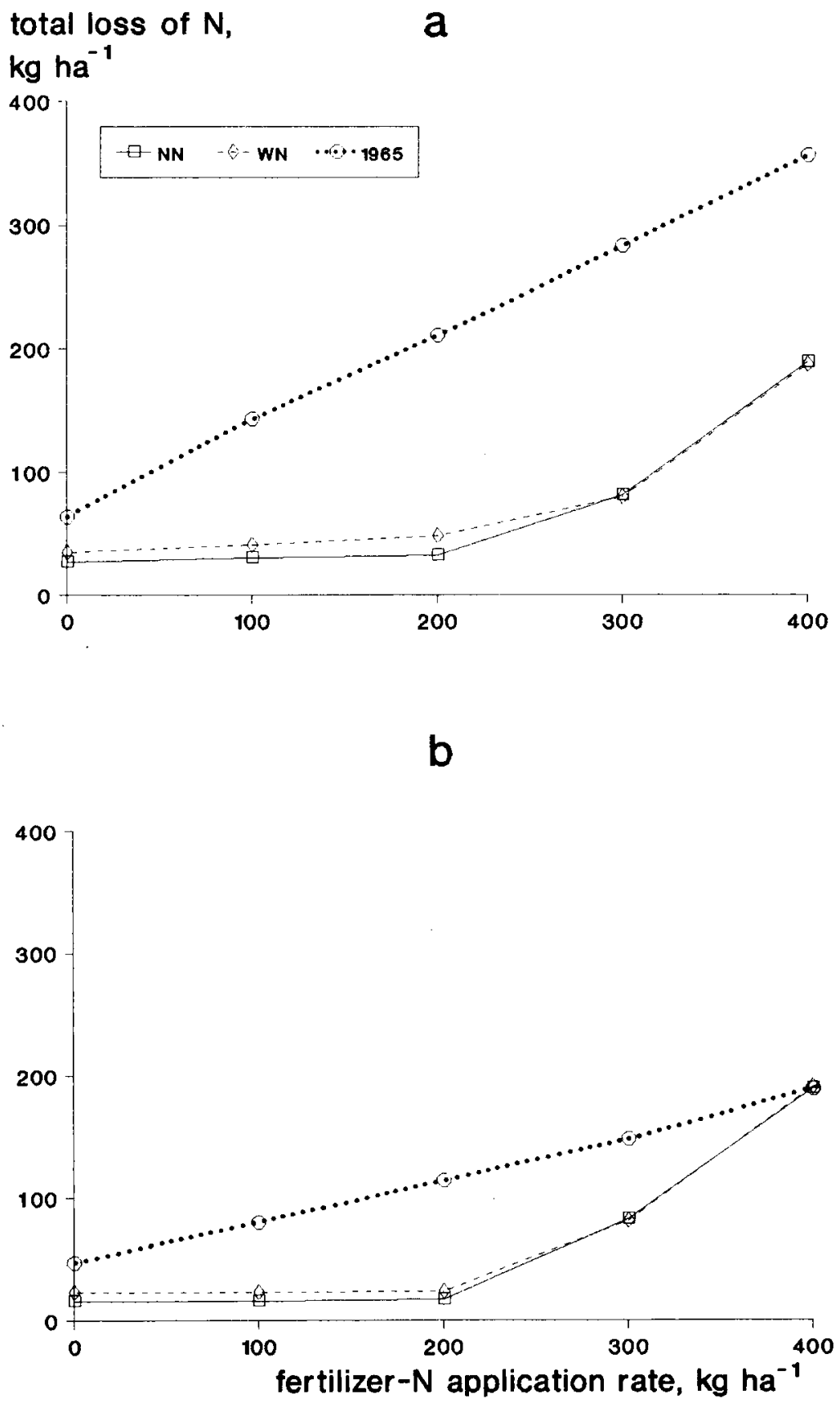

Fig. 10. Total loss of nitrogen due to leaching in spring and accumulation of residual soil mineral nitrogen in the loamy sand (a) and the clay loam (b) after a normal, a wet, and an extremely wet spring. Mineralization rate is $1 \mathrm{~kg} \mathrm{~N}$ per ha per day. 


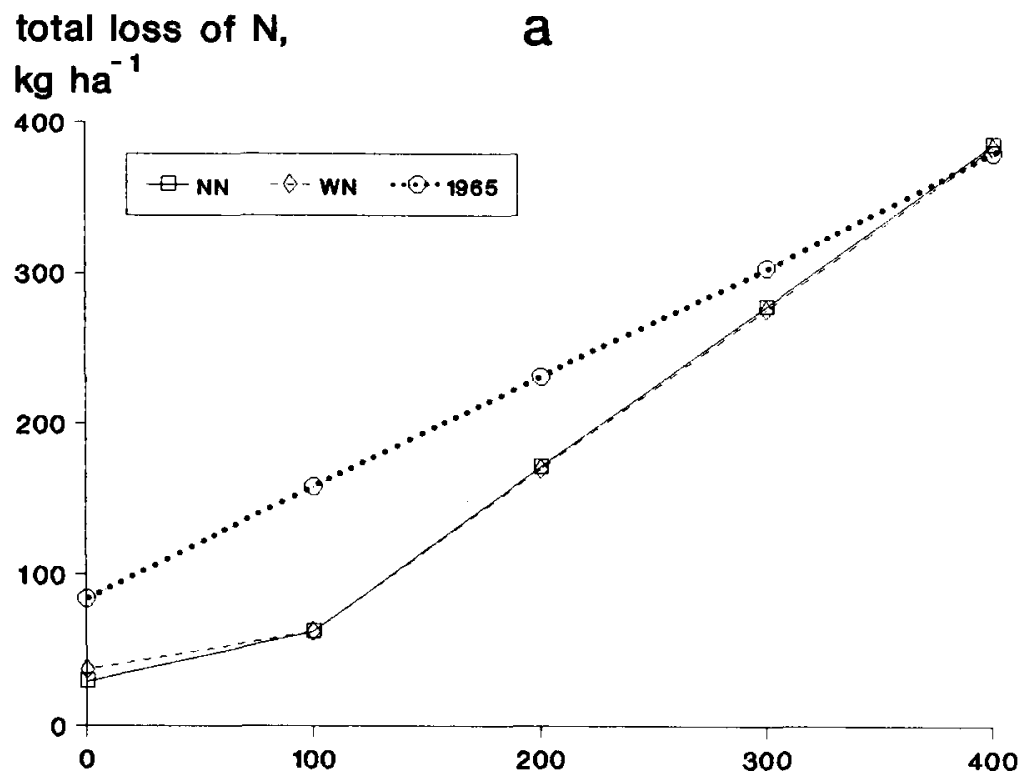

b

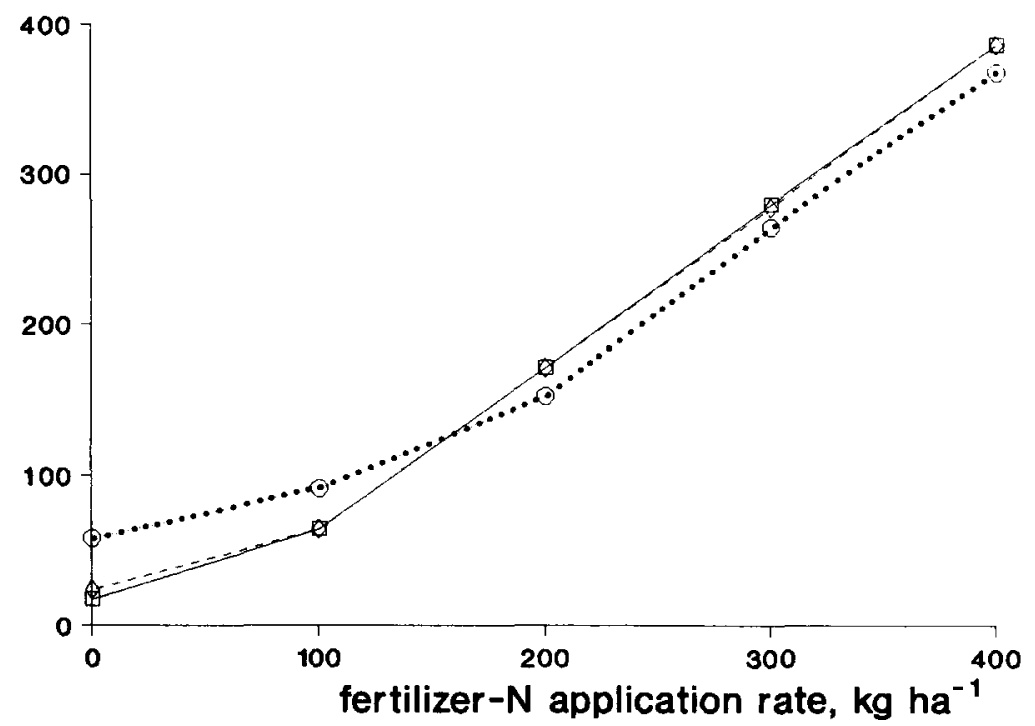

Fig. 11. Total loss of nitrogen due to leaching in spring and accumulation of residual soil mineral nitrogen in the loamy sand (a) and the clay loam (b) after a normal, a wet, and an extremely wet spring. Mineralization rate is $2 \mathrm{~kg} \mathrm{~N}$ per ha per day. 
ference between, on the one hand, the sum of the initial amount of soil mineral nitrogen (1 March), the amount of fertilizer nitrogen applied, and the amount of nitrogen mineralized from 1 March onwards, and on the other hand, the sum of the amount of nitrogen recovered by the tops and tubers of the potato crop, the amount of nitrogen leached from 1 March onwards, and the amount of nitrogen not recovered by the tops and tubers. When the crop absorbs nitrate from soil, less nitrogen appears in the foliage and tubers than 'disappears' from soil, even when there is no leaching. This 'disappearance' is set in the model to vary between 20 and $35 \%$ as described earlier (Section 'Materials and methods'). It covers immobilization of nitrogen by the microbial biomass, denitrification, ammonia volatilization, and incorporation of nitrogen into fibrous roots, processes which are not explicitly described in the model. Nitrogen which is present in leaves shed during senescence is also assumed to be included in the fraction of nitrogen that disappears. The contribution of the other processes which are not explicitly described by the model may vary depending on site and weather conditions, thus making the value of the amount of the nitrogen not recovered by the tops and tubers in the balance sheet rather uncertain. However, attempts to describe processes in more detail have as yet not seemed to improve the validity of models used for practical purposes (de Willigen \& Neeteson, 1985; Neeteson \& van Veen, 1988).

After normal and wet springs the mineralization rate in the soil and the soil type did not affect the amount of residual soil mineral nitrogen. However, after the extremely wet spring of 1965 , at the high mineralization rate, and at the higher levels of fertilizer nitrogen application, more residual soil mineral nitrogen was calculated to be present in the clay loam than in the loamy sand due to the fact that the nitrate supply by the soil exceeded crop demand. In the loamy sand more of this surplus was lost due to leaching, so that less was left unused by the crop and could thus be found as residual soil mineral nitrogen.

Under average conditions of precipitation and mineralization, residual soil mineral nitrogen started to accumulate at fertilizer nitrogen application rates exceeding $200 \mathrm{~kg} \mathrm{~N}$ per ha. At the high level of nitrogen mineralization, however, accumulation began when the application rate was only $100 \mathrm{~kg} \mathrm{~N}$ per ha. If the optimum application rates of fertilizer nitrogen had been applied, i.e. at the average rate of mineralization about $200 \mathrm{~kg} \mathrm{~N}$ per ha on the loamy sand and about $150 \mathrm{~kg} \mathrm{~N}$ per ha on the clay loam and at the high rate of mineralization $0-20 \mathrm{~kg} \mathrm{~N}$ per ha (Fig. 4), no accumulation of residual soil mineral would have occurred (Fig. 9). In a series of nitrogen-fertilizer trials with starch potatoes on sandy soils and cut-over peat soils, Wadman et al. (1990) found that residual soil mineral nitrogen in the 0-60 cm layer averaged $27 \mathrm{~kg} \mathrm{~N}$ per ha without application of fertilizer nitrogen and $84 \mathrm{~kg} \mathrm{~N}$ per ha with the optimum application rate of fertilizer nitrogen. Thus they found an accumulation of $57 \mathrm{~kg}$ residual soil mineral $\mathrm{N}$ per ha. The difference between the amount accumulated according to calculations in the model and the findings of Wadman et al. is probably due to the assumption in the model that 20 to $30 \%$ of soil mineral nitrogen 'disappears'. Since residual soil mineral nitrogen in the trials of Wadman et al. was determined about 45 days later than was assumed in the model, it is quite possible that a large part of the nitrogen present in the leaves shed during 
senescence of the starch potatoes had already mineralized at that time. Another explanation for the larger amount of residual nitrogen accumulated could be that nitrogen uptake by, and growth of, the starch potatoes were impeded by drought, because the growing seasons of 1983-1985, the period in which the trials were performed (Wadman et al., 1990), were rather dry.

\section{Total amount of nitrogen lost}

If the currently recommended amounts of fertilizer nitrogen (Neeteson, 1989a) of $305 \mathrm{~kg} \mathrm{~N}$ per ha for the loamy sand and $265 \mathrm{~kg} \mathrm{~N}$ per ha for the clay loam had been applied and the mineralization rate was average, the total loss due to leaching in a normal spring and due to accumulation of residual soil mineral nitrogen would have been $88 \mathrm{~kg} \mathrm{~N}$ per ha for loamy sand and $45 \mathrm{~kg} \mathrm{~N}$ per ha for clay loam. At the high mineralization rate, the total loss from the loamy sand would have been $288 \mathrm{~kg} \mathrm{~N}$ per ha and that from the clay loam $239 \mathrm{~kg} \mathrm{~N}$ per ha. Assuming that the precipitation surplus is $300 \mathrm{~mm}$ water - the usual amount in the Netherlands - the EEC maximum permissible concentration for drinking water of $11.3 \mathrm{mg}$ nitrate-N per litre (Anon., 1980 ) is reached when $34 \mathrm{~kg} \mathrm{~N}$ per ha is leached out. This means that the EEC standard is exceeded when potatoes are given the currently recommended amounts of nitrogen, especially so when mineralization rates are high. In a previous paper (Neeteson, 1989b) it was shown that a $25 \%$ reduction in the recommended amounts of fertilizer nitrogen for potatoes did not affect yield. If the above-mentioned recommended amounts of nitrogen are reduced by $25 \%$, the total loss of nitrogen would be $33 \mathrm{~kg} \mathrm{~N}$ per ha in the case of the loamy sand and $22 \mathrm{~kg} \mathrm{~N}$ per ha in the case of the clay loam at the average rate of mineralization. Thus, when the currently recommended amounts of fertilizer nitrogen for potatoes are reduced by $25 \%$, it appears that under normal conditions a high yield will be obtained without exceeding the maximum permissible nitrate concentration in water to be used for human consumption. However, at the high rate of mineralization, a reduction of the recommended amounts of nitrogen by $25 \%$ would still result in excessive losses: 205 and $167 \mathrm{~kg} \mathrm{~N}$ per ha for the loamy sand and the clay loam, respectively. Since it is difficult to predict mineralization rates for individual fields, research aimed at finding simple ways to determine mineralization levels by means of incubation or chemical extraction (Stanford, 1981) should be continued. When the mineralization rate of a specific field can be predicted, the recommended amount of fertilizer nitrogen can be lowered considerably when mineralization rates are high; severe losses of nitrogen can thus be avoided.

\section{References}

Anon., 1980. Council directive on the quality of water for human consumption. Official Journal of the European Economic Community 23, 80/778 EECL 229: 11-29.

Anon., 1989. Monthly review of the weather conditions (in Dutch). Koninklijk Nederlands Meteorologisch Instituut, De Bilt. 


\section{J. J. NEETESON, D. J. GREENWOOD AND A. DRAYCOTT}

Anon., 1906-1988. Monthly review of the precipitation in the Netherlands (in Dutch). Koninklijk Nederlands Meteorologisch Instituut, De Bilt.

Burns, I. G., 1974. A model for predicting the redistribution of salts applied to fallow soils after excess rainfall or evaporation. Journal of Soil Science 25: 165-178.

Duynisveld, W. H. M., O. Strebel \& J. Böttcher, 1988. Are nitrate leaching from arable land and nitrate pollution of groundwater avoidable? Ecological Bulletins 39: 116-125.

Dyson, P. W. \& D. J. Watson, 1971. An analysis of the effects of nutrient supply on the growth of potato crops. Annals of Applied Biology 69: 47-63.

Greenwood, D. J. \& A. Draycott, 1989. Experimental validation of an $\mathrm{N}$-response model for widely different crops. Fertilizer Research 18: 153-174.

Greenwood, D. J., J. J. Neeteson \& A. Draycott, 1985a. Response of potatoes to N fertilizer: quantitative relations for components of growth. Plant and Soil 85: 163-183.

Greenwood, D. J., J. J. Neeteson \& A. Draycott, 1985b. Response of potatoes to N fertilizer: dynamic model. Plant and Soil 85: 185-203.

Neeteson, J. J., 1989a. Evaluation of the performance of three advisory methods for nitrogen fertiliza tion of sugar beet and potatoes. Netherlands Journal of Agricultural Science 37: 143-155.

Neeteson, J. J., 1989b. Effect of reduced fertilizer nitrogen application rates on yield and nitrogen recovery of sugar beet and potatoes. Netherlands Journal of Agricultural Science 37: 227-236.

Neeteson, J. J. \& J. A. van Veen, 1988. Mechanistic and practical modelling of nitrogen mineralizationimmobilization in soils. In: J. R. Wilson (Ed.), Advances in Nitrogen Cycling in Agricultural Ecosystems, p. 145-155. CAB International, Wallingford.

Neeteson, J. J., D. J. Greenwood \& A. Draycott, 1987. A dynamic model to predict yield and optimum nitrogen fertiliser application rate for potatoes. Proceedings 262. The Fertiliser Society, London, 31 pp.

Prins, W. H., K. Dilz \& J. J. Neeteson, 1988. Current recommendations for nitrogen fertilisation within the EEC in relation to nitrate leaching. Proceedings 276. The Fertiliser Society, London, $27 \mathrm{pp}$.

Stanford, G., 1981. Assessment of soil nitrogen availability. In: F. J. Stevenson (Ed.), Nitrogen in Agricultural Soils, p. 651-688. Agronomy 22. American Society of Agronomy, Madison.

Wadman, W. P., J. J. Neeteson \& G. Wijnen, 1990. Effects of slurry with and without the nitrification inhibitor dicyandiamide on soil mineral nitrogen and nitrogen response of potatoes. In: J. Aa. Hansen \& K. Henriksen (Eds), Proceedings Symposium 'Nitrogen in Organic Wastes', Aalborg, Denmark (in press).

Willigen, P. de, 1986. Supply of soil nitrogen to the plant during the growing season. In: H. Lambers, J. J. Neeteson \& I. Stulen (Eds), Fundamental, Ecological and Agricultural Aspects of Nitrogen Metabolism in Higher Plants, p. 417-432. Martinus Nijhoff Publishers, Dordrecht.

Willigen, P. de \& J. J. Neeteson, 1985. Comparison of six simulation models for the nitrogen cycle in the soil. Fertilizer Research 8: 157-171.

Wösten, J. H. M., M. H. Bannink \& J. Beuving, 1987. Water retention and hydraulic conductivity characteristics of top and subsoils in the Netherlands: the Staring Series (in Dutch). Report 1932, Stichting voor Bodemkartering, Wageningen, $76 \mathrm{pp}$. 